\title{
Resilience in Sports: A Qualitative Discussion on Risk Factors and Protective Factors among Performance Development (Pd) Athletes
}

Nur Haziyanti Mohamad Khalid, Nelfianty Mohd Rasyid, Yusop Ahmad

To Link this Article: http://dx.doi.org/10.6007/IJARBSS/v11-i12/11589 DOI:10.6007/IJARBSS/v11-i12/11589

Received: 15 October 2021, Revised: 18 November 2021, Accepted: 30 November 2021

Published Online: 13 December 2021

In-Text Citation: (Khalid et al., 2021)

To Cite this Article: Khalid, N. H. M., Rasyid, N. M., \& Ahmad, Y. (2021). Resilience in Sports: A Qualitative Discussion on Risk Factors and Protective Factors among Performance Development (Pd) Athletes. International Journal of Academic Research in Business and Social Sciences, 11(12), 125-138.

Copyright: (c) 2021 The Author(s)

Published by Human Resource Management Academic Research Society (www.hrmars.com) This article is published under the Creative Commons Attribution (CC BY 4.0) license. Anyone may reproduce, distribute, translate and create derivative works of this article (for both commercial and non0-commercial purposes), subject to full attribution to the original publication and authors. The full terms of this license may be seen at: http://creativecommons.org/licences/by/4.0/legalcode

$$
\text { Vol. 11, No. 12, 2021, Pg. } 125-138
$$

Full Terms \& Conditions of access and use can be found at http://hrmars.com/index.php/pages/detail/publication-ethics 


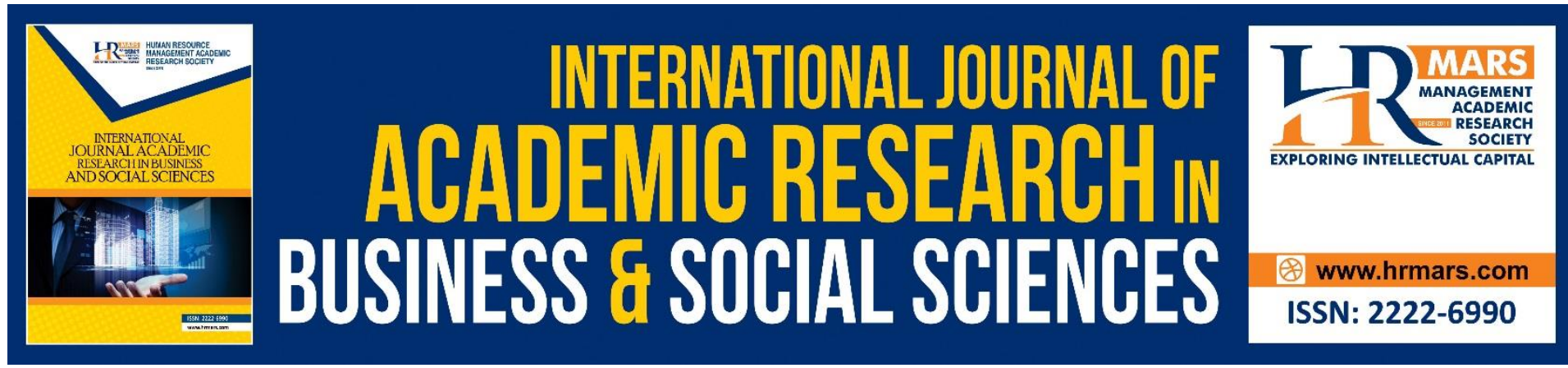

\title{
Resilience in Sports: A Qualitative Discussion on Risk Factors and Protective Factors among Performance Development (Pd) Athletes
}

\section{Nur Haziyanti Mohamad Khalid, Nelfianty Mohd Rasyid, Yusop Ahmad}

Faculty of Sports Science and Coaching, Sultan Idris Education University, Malaysia Email: nur.haziyanti@fsskj.upsi.edu.my,nelfianty@fsskj.upsi.edu.my, yusop@fsskj.upsi.edu.my

\begin{abstract}
Athletes who reach a developed performance level, faced various challenges and difficulties, but they are still able to remain resilient. This study was conducted to explore the aspects of resilience among athletes within Performance Development (PD) category. Focused group discussions using semi-structured interview based on Multilevel Classification System for Sport Psychology (MCS-SP) model were conducted on 20 Perak state athletes who were undergoing Malaysia Sports Game 2021 (SUKMA) preparation program. The results of the study found five themes related to risk factors faced by athletes in maintaining developing performance such as performance, change, behavior, psychology and interpersonal issues. The study suggested that acceptance and commitment as part of psychological protective factors that help athletes maintain resilience. The study also produced a model of resilience among PD athletes which can be used as a reference in sports training programs.
\end{abstract}

Keywords: Resilience, Multilevel Classification System for Sport Psychology (MCS-SP), Performance Development (PD), Risk Factor, Protective Factor

\section{Introduction}

Athletes need to optimize physical and psychological skills to deal with competition stress, in high-level sports (Fletcher \& Sarkar, 2012). Studies show that different types of sources of stress need to be addressed in a competition, while psychological characteristics help athletes adapt to obstacles and changes throughout the participation (MacNamara, Button \& Collins, 2010; McKay et al., 2008). Performance, organizational environment, or social and personal life events, are used to be the causes for athletes to face stress (Sarkar \& Fletcher, 2014). While the ability to respond positively to stress and adversity, referred as resilient is indispensable in sports (Luthar et al., 2000; Mills et al., 2012). Resilience is important because those who are resilient have the ability to maintain functional patterns after facing challenges and risk factors, as well as the ability to recover quickly from trauma that has led to changes in their life organization (McCubbin et al., 1997). 
The initial definition of resilience is to bounce back from stress experience quickly and efficiently (Carver \& Schieier, 1998), and achieve the status of equilibrium in performance (Luthar, Cicchetti \& Becker, 2000). Resilience also refers to the qualities formed as a result of interactions between individuals and the cultural, social and political context, around them (Giligan, 2004). According to Ungar (2008), resilience is the ability of an individual to lead life towards more sustainable well-being. Fletcher and Sarkar (2013) define resilience in the context of sports performance as the role of mental processes and behaviors to promote personal assets and protect individuals from the negative effects of stress sources. For example, although Olympic gold medalists face various sources of stress from the normative (such as the balance between career and training) and the non-normative (such as the death of a family member), they are able to protect themselves from negative effects through perception and meta-cognitive skills that ultimately results in optimal performance. Perception and meta-cognitive skills are meant to refer to the characteristics of personality skills, motivation, self-confidence, focus, and social support that form a relationship between resilient-stress-performance (Fletcher \& Sarkar, 2013). Thus, the study of resilience in sports aims to understand the individual differences in adapting to various sources of stress (Fletcher \& Sarkar, 2012).

Among the challenges that cause stress to athletes are injuries (Podlog \& Eklund, 2006), relationship factors (Mellalieu, Shearer \& Shearer, 2013), organizational needs (Fletcher \& Hanton, 2003), and mental health problems (Papathomas \& Lavallee, 2012). The way athletes respond to difficulty in maintaining performance is different from each other. Only those who are able to recover from the impact of stress are considered resilient (Gallia \& Gonzalez, 2014). According to Galli and Gonzales (2014), there are two approaches in studying resilience in sports. The first is a study that examines the psychosocial factors that influence performance. Resilience is seen as a successful performance behavior after dealing with previous poor performance. Second, resilience is seen based on the thinking, belief, emotional and behavioral abilities of athletes who successfully adapt to difficulties in sports (Galli \& Gonzales, 2014). While, there are views that resilience is a complex process with a multitude of underlying variables, Hill et al (2018) have propose the dynamical system approach that provides a theoretical perspective on mapping out and understanding how resilience as an interactive process that is driven by ongoing interactions among a multitude of variables.

Studies by Mummery, Schofield and Perry (2004) identify the factors that influence resilience and how athletes can form resilience. In addition, studies on resilience were also conducted among adolescents (Galli \& Vealey, 2008), and spinal patients (Machida, Irwin, \& Feltz, 2013). There are also issues of overlapping resilient constructs with other psychological constructs such as perseverance (Howe, Smajdor \& Stokl, 2012; Windle, 2011), coping (Campbell-Sills, Cohan, \& Stein, 2006; Leipold \& Greve, 2009; Rutter, 2012), mental strength (Gucciardi \& Gordon, 2009), and post-traumatic development (Westphal \& Bonanno, 2007). Mohamad Khalid, Mat Isa and Md Fadhil (2018) in their study showed the importance of assessing the level of mental skills as a source of resilience among Perak Bowling athletes. Nonetheless, Mohamad Khalid (2008) found that academic factors are the highest risk factors that contribute to stress in the resilience process of collegiate athletes. Thus, the relationship between risk factors and protective factors, with decreased rates of depression, anxiety and stress, gives a clear picture that college athletes need strong protective factors in terms of 
resilience strength, emotional intelligence and locus of internal control to produce positive adaptation to adversity. A study of the relationship between resilience and sports performance by Hosseinia and Besharata (2010) also found that resilience is positively related to sports performance and mental well-being, and has a negative relationship with psychological distress.

\section{Current Study}

Model of Multilevel Classification System for Sport Psychology (MCS-SP) explains that among factors that influencing athlete resilience are performance demands; environmental changes and challenges; thought, affective and behavioral patterns; specific physical skills; interpersonal and intrapersonal variables, and developmental factors (Gardner \& Moore, 2006). Based on this model, Gardner and Moore (2006) introduced a classification system in Clinical Sports Psychology to identify psychological and behavioral characteristics, which serve as a boundary to indicate the performance function of athlete. The MCS-SP classification system aims to differentiate athlete issues and problems into four types of performance functions such as Performance Development (PD), Performance Dysfunction (PDy), Performance Impairment (PI) and Performance Termination (PT). The purpose of the MCS-SP is to propose holistic assessment methods to understand athlete problems, to formulate appropriate intervention strategies to improve athlete performance, and to produce intervention studies for more specific athlete issues.

Khalid et al (2017) proposed MCS-SP as a standard reference to identify the functional status and the preparation of psychological intervention planning for University Sport Council collegiate athletes. MCS-SP model provides interview administration guidelines to obtain athlete performance function information, while the case formulation resulting from these interviews can provide information related to risk factors, protective factors and restorative factors that can determine the overall athlete resilience index. There are eight elements of case formulation based on MCS-SP model to understand athlete performance issues such as contextual performance needs, athlete performance level, relevant situation needs, athlete psychological characteristics, behavioral response, self-regulatory profile, willingness to change and reactance level. According to Gardner and Moore (2006), there is no such instrument to measure the index or level of each sub-scale of performance function. If any, it is only the Performance Classification Questionnaire (PCQ), which is used to differentiate the classification of PD and PDy athletes (Gardner et al., 2005).

Figure 1 explains the MCS-SP model for the classification of performance functions. Based on these models, PD athletes tend to improve sports performance, and are not affected by any psychological well-being issues. There are no factors such as development, transition, behavior, interpersonal and intrapersonal that can affect performance, or that require the attention of sports psychologists. However, the views of PD athletes on issues that can affect performance is important so that it can be used as an indicator of the resilience domain that needs to be understood by athletes who want to achieve PD status. Therefore, the selection of participants among PD athletes is important for this study. 
Fig.1. Classification of athlete's category based on Multilevel Classification System for Sport Psychology (MCS-SP)

\begin{tabular}{|c|c|c|}
\hline Category & Characteristics & Suggestion \\
\hline $\begin{array}{l}\text { Performance } \\
\text { Development } \\
\text { (PD): }\end{array}$ & $\begin{array}{l}\text { Psychological skill training requirement to improve the } \\
\text { performance become as the main goal. There is no } \\
\text { growth factor, transition, behavioral, and interpersonal } \\
\text { and intrapersonal factors that could affect } \\
\text { performance, or that require the attention of sport } \\
\text { psychology practitioners. }\end{array}$ & $\begin{array}{l}\text { PD athletes are } \\
\text { strongly } \\
\text { encouraged to } \\
\text { follow the } \\
\text { psychological } \\
\text { skill training to }\end{array}$ \\
\hline PD-I & $\begin{array}{l}\text { In the PD-I category, the development of physical skill } \\
\text { still needs to be improved. Psychological skill training is } \\
\text { needed for the purpose of improving the physical skill } \\
\text { and overall performance. }\end{array}$ & $\begin{array}{l}\text { improve the skill } \\
\text { of self- } \\
\text { regulation. }\end{array}$ \\
\hline PD-II & $\begin{array}{l}\text { Physical skill is fully developed to a high level, but the } \\
\text { psychological skill is needed to maintain an optimal } \\
\text { level of performance and consistency. }\end{array}$ & \\
\hline $\begin{array}{l}\text { Performance } \\
\text { Dysfunction } \\
\text { (PDy): }\end{array}$ & $\begin{array}{l}\text { PST requirement is to improve the performance as the } \\
\text { first or second goal. Performance may already well } \\
\text { developed and consistent, or perhaps still slow and } \\
\text { late. However, athletes are faced with psychological } \\
\text { barriers such as developmental problems, changes, } \\
\text { interpersonal, intrapersonal (the issue of the mental } \\
\text { scheme establishment, perception, personality and } \\
\text { behavioral characteristics) which bring the negative } \\
\text { impact on athletes. This factor is indirectly reducing the } \\
\text { overall level of psychological and physical behavior } \\
\text { either chronically or according to the situation. }\end{array}$ & $\begin{array}{l}\text { PDy athletes are } \\
\text { encouraged to } \\
\text { attend } \\
\text { counseling } \\
\text { programme } \\
\text { beforehand and } \\
\text { followed with } \\
\text { psychological } \\
\text { skills training. }\end{array}$ \\
\hline PDy-I & $\begin{array}{l}\text { External life factors such as the developmental aspect, } \\
\text { transition and interpersonal triggered the } \\
\text { psychological reactions that result in dysfunction } \\
\text { performance. } \\
\text { Internal life factors such as thinking schemes and } \\
\text { behavioral characteristics triggered by the competition } \\
\text { environment or competition cues during performance, } \\
\text { resulting in dysfunction performance. }\end{array}$ & \\
\hline $\begin{array}{l}\text { Performance } \\
\text { Impairment (PI) }\end{array}$ & $\begin{array}{l}\text { Clinical issues that clearly exist, causing athletes to } \\
\text { suffer from emotional depression and extremely } \\
\text { unstable behavior, resulting in total decreased of } \\
\text { performance. The existence of the clinical issues, } \\
\text { causes a severe deterioration of the performance, at } \\
\text { least in one (usually more) major life domain, such as } \\
\text { family, interpersonal, social, career or education. }\end{array}$ & $\begin{array}{l}\text { PI athletes are } \\
\text { encouraged to } \\
\text { fltend } \\
\text { counseling } \\
\text { tand / or } \\
\text { psychotherapy }\end{array}$ \\
\hline
\end{tabular}




\begin{tabular}{|c|c|}
\hline & $\begin{array}{l}\text { Counseling psychological treatment or intensivethe addition of } \\
\text { psychotherapy efforts are used to recover } \mathrm{PI} \text {, while the medicine, then } \\
\text { performance improvement is the second agenda in thefollowed with } \\
\text { intervention until the clinical issue can be resolved. Theinterventions to } \\
\text { use of traditional psychological skill training is seen not increase } \\
\text { giving effective impact due to the existence of obviousperformance. } \\
\text { clinical issues. }\end{array}$ \\
\hline PI-I & $\begin{array}{l}\text { There were issues of clinical disorders such as affective } \\
\text { disorder, anxiety disorder, eating disorder, alcohol and } \\
\text { substance abuse, Post Traumatic Stress Disorder, } \\
\text { causing severe damage to the overall function of life } \\
\text { and inability to participate in competition. }\end{array}$ \\
\hline PI-II & $\begin{array}{l}\text { There were issues of failure in self-regulation such as } \\
\text { anger disorder/instinct control, drug/alcohol abuse, } \\
\text { and domestic violence/relationship, causing significant } \\
\text { damage in the major domain of life (like family) and } \\
\text { limitation of participation in competition either for } \\
\text { short or long duration (such as suspension from the } \\
\text { team, expelled from the game, legal action or } \\
\text { detention). }\end{array}$ \\
\hline $\begin{array}{l}\text { Performance } \\
\text { Termination } \\
\text { (PT): }\end{array}$ & $\begin{array}{l}\text { There were issues related to the career termination Athletes are } \\
\text { due to serious injury, voluntary or forced resignation. encouraged to } \\
\text { Psychological reactions may occur such as anger, follow career } \\
\text { depression, and anxiety in the athletes and theircounseling } \\
\text { families. Athletes can choose to get counseling or programme and } \\
\text { specific psychosocial treatment in terms of career and counseling } \\
\text { financial planning. }\end{array}$ \\
\hline $\mid 1-1$ & $\begin{array}{l}\text { Career ending as due to expected factors such as self- } \\
\text { choice, age, and natural reduction of physical skills. } \\
\text { Psychology reaction shown used to be normal, but } \\
\text { sometimes may indicate a sequence of sub-clinical } \\
\text { symptom such as shock, sadness, denial, anger, } \\
\text { depression or acceptance. }\end{array}$ \\
\hline PT-II & $\begin{array}{l}\text { Career ending as due to unforeseen circumstances such } \\
\text { as serious injury, or termination without cause of } \\
\text { injuries. Effects of psychological reaction are worse } \\
\text { than the PT-I such as Acute Stress Reaction, or Post } \\
\text { Traumatic Stress Disorder. Treatment needed is a } \\
\text { higher intensity. }\end{array}$ \\
\hline
\end{tabular}

To make this study successful, we use the MCS-SP model as a guideline in the implementation of qualitative research to obtain the desired information. In this study researchers aim to identify: 
the risk factors faced by PD athletes in their struggles throughout the training program, and the protective factors that help them to maintain resilience.

\section{Method \\ Design}

Focused group discussions are conducted to gather a group of individuals to discuss specific topics, aimed at gaining information on the experiences, beliefs, perceptions and attitudes of group members, through semi-structured interview techniques, conducted by professional members (Hayward, Simpson \& Wood, 2004). This study has also used a convenient sampling method, as this technique depends on the ability and capacity of the participants to provide relevant information (Morgan, 1988). While it is generally accepted that between six and eight participants is sufficient for a focused group discussion (Krueger \& Casey, 2000), some studies have reported at least four, and at most fifteen participants are adequate (Fern, 1982; Mendes de Almeida, 1980).

\section{Participants}

A total of 20 athletes under Perak State Sports Council, Malaysia, who are undergoing preparatory training for SUKMA 2021 have been selected as participants, and have attended a focused group discussion in January 2020. The age of the participants ranged from 18 to 21 years old. Based on the initial diagnosis using Performance Classification Questionnaire (PCQ) (Gardner et al., 2005), all participants are from the category of Performance Development (PD). In line with the definition of resilience given by Fletcher and Sarkar (2013) that resilience as the role of mental and behavioral processes in promoting personal assets and protecting individuals from the negative effects of stressors, the selection of Perak state athletes is appropriate for this study. The athletes have already gone through phases of difficulty in performance before being able to reach the level of participation in the Malaysian Games (SUKMA), and also the goal of this study is to identify the characteristics and domains of resilience possessed by PD athletes.

\section{Measures}

This study has used semi-structured interview methods, while researchers serve as facilitators (Parker \& Tritter, 2006; Burrows \& Kendall, 1997; Krueger, 1994). The main methods of data collection during focused group discussions include audio recordings, written notes and observations of participant behavior (Stewart, Shamdasani \& Rook, 2007). Discussion activities were conducted within an hour to avoid fatigue and boredom of the participants. Semi-structured interview guidelines have been carefully planned and carefully implemented by researchers based on the Multilevel Classification System for Sport Psychology (MCS-SP) model. The basic questions asked during the discussion were based on PD module as found in the MCS-SP semi-structured interview guidelines in Table 1. 
Table 1

Semi-Structured Interview Guidelines based on Multilevel Classification System Model for Sport Psychology (PD Module)

\begin{tabular}{|c|c|c|c|}
\hline BIL & \multicolumn{3}{|c|}{ MODUL PERFORMANCE DEVELOPMENT (PD) } \\
\hline 1 & $\begin{array}{l}\text { Tell me about the performance issues } \\
\text { you wish to work on. (Note any } \\
\text { performance strengths and } \\
\text { weaknesses, } \\
\text { performance, brief or extended } \\
\text { slumps, and so son) }\end{array}$ & $\begin{array}{l}\text { Performance } \\
\text { enhancement } \\
\text { is the primary } \\
\text { goal? Yes or No }\end{array}$ & $\begin{array}{l}\text { If yes, continue } \\
\text { through the remaining } \\
\text { questions for PD and } \\
\text { PDy. If No, skip to PI } \\
\text { module. If response } \\
\text { suggests issues } \\
\text { relating to career } \\
\text { termination (recent, } \\
\text { impending, or near } \\
\text { future) proceed to PT } \\
\text { module. }\end{array}$ \\
\hline 2 & $\begin{array}{l}\text { Tell me about any new, changing, or } \\
\text { special circumstances in your life in } \\
\text { and out of sports at this time }\end{array}$ & $\begin{array}{l}\text { Transitional } \\
\text { issues: } \\
\text { YES or NO }\end{array}$ & \\
\hline 3 & $\begin{array}{l}\text { Are there any recent incidents or } \\
\text { situations that put you in trouble or } \\
\text { cause you trouble? }\end{array}$ & $\begin{array}{l}\text { Behavioral } \\
\text { issues: } \\
\text { YES or NO }\end{array}$ & \\
\hline 4 & $\begin{array}{l}\text { Are there any tense feelings or } \\
\text { emotions at this time that you find } \\
\text { difficult or seemingly unusual? If YES, } \\
\text { what is the situation, and how do you } \\
\text { try to overcome it? } \\
\text { (Be careful when exploring the } \\
\text { emotions and behaviors of such coping } \\
\text { strategies). }\end{array}$ & $\begin{array}{l}\text { Emotional or } \\
\text { psychological } \\
\text { distress: } \\
\text { YES or NO }\end{array}$ & $\begin{array}{l}\text { If response no. } 2 \text { - } 5 \text { all } \\
\text { are NO, proceed to } \\
\text { answer the rest of the } \\
\text { PD module. } \\
\text { If one of the responses } \\
\text { no. } 2-5 \text { is YES, } \\
\text { immediately move to } \\
\text { PDy module. }\end{array}$ \\
\hline 5 & $\begin{array}{l}\text { Tell me about your present } \\
\text { relationship with the individuals } \\
\text { around you (coaches, teammates, } \\
\text { staff, friends, family, significant others, } \\
\text { and so on). }\end{array}$ & $\begin{array}{l}\text { Interpersonal } \\
\text { Conflict: } \\
\text { YES or NO }\end{array}$ & \\
\hline 6 & $\begin{array}{l}\text { To what extent have you tried to } \\
\text { improve your performance before? } \\
\text { How effective is it for you? How do you } \\
\text { explain the effort and intensity of your } \\
\text { training? }\end{array}$ & $\begin{array}{l}\text { For questions } 6 \\
\text { to } 9 \text {, evaluate } \\
\text { the } \\
\text { development } \\
\text { of physical and } \\
\text { mental skills. }\end{array}$ & \\
\hline 7 & $\begin{array}{l}\text { State clearly about your sports goals. } \\
\text { To what extent is the goal appropriate? } \\
\text { Does anyone inform whether the goal } \\
\text { is reasonable or not? }\end{array}$ & & \\
\hline
\end{tabular}




\begin{tabular}{|c|c|c|c|}
\hline 8 & $\begin{array}{l}\text { Tell me about your focus and } \\
\text { concentration during training and } \\
\text { competitions. How often do you feel } \\
\text { disturbed? What thoughts, emotions } \\
\text { or situations are bothering you? What } \\
\text { do you do to reduce distractions and } \\
\text { maintain concentration? }\end{array}$ & & \\
\hline 9 & $\begin{array}{l}\text { Tell me how you react when you get } \\
\text { frustrated. What do you think and feel } \\
\text { during this frustration? What do you } \\
\text { do to respond to frustration? To what } \\
\text { extent does it affect you? }\end{array}$ & & $\begin{array}{l}\text { Use the answers to } \\
\text { questions 5-9 as a } \\
\text { framework to } \\
\text { determine } \\
\text { appropriateness of } \\
\text { psychological } \\
\text { interventions to } \\
\text { improve performance. } \\
\text { If psychological } \\
\text { intervention } \\
\text { (psychological skills } \\
\text { training) may help, } \\
\text { consider } \\
\text { (Performance } \\
\text { Development) } \\
\text { classification. }\end{array}$ \\
\hline 10 & $\begin{array}{l}\text { To what extent do you believe that you } \\
\text { are still developing your physical and } \\
\text { technical skills? Do you believe that } \\
\text { you are still quite far from the } \\
\text { optimum level }\end{array}$ & $\begin{array}{l}\text { Positive } \\
\text { feedback } \\
\text { suggests a } \\
\text { classification } \\
\text { of PD-I }\end{array}$ & \\
\hline 11 & $\begin{array}{l}\text { To what extent do believe that you } \\
\text { have reached a high level of skill, or } \\
\text { you may have reached the peak of } \\
\text { performance, but still need help to get } \\
\text { better or more consistent } \\
\text { performance? }\end{array}$ & $\begin{array}{l}\text { Positive } \\
\text { feedback } \\
\text { suggests a } \\
\text { classification } \\
\text { of PD-II }\end{array}$ & 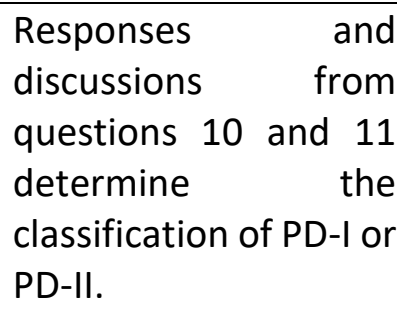 \\
\hline
\end{tabular}

\section{Result and Discussion}

Based on responses from the focus group discussion, researchers performed verbatim transcripts, read and made open coding analysis line by line to ensure substantive code or theme could be produced. After the data were examined, five key themes related to risk factors were identified based on the indicators reported by the participants. In addition, also found is a theme that leads to protective factors that participants refer as asset used by them to protect performance from being influenced by risk factors. Detailed information on risk factors and protective factors derived from this study is explained in Table 2. 
Table 2

Themes and indicators of risk and protective factors among PD athletes

\begin{tabular}{|c|c|c|c|}
\hline & $\begin{array}{l}\text { INDICATORS OF RISK } \\
\text { FACTORS ON PERFORMANCE } \\
\text { DEVELOPMENT }\end{array}$ & & $\begin{array}{l}\text { INDICATORS OF } \\
\text { PROTECTIVE FACTORS } \\
\text { ON PERFORMANCE } \\
\text { DEVELOPMENT } \\
\end{array}$ \\
\hline $\begin{array}{l}\text { Performance } \\
\text { Issues }\end{array}$ & $\begin{array}{l}\text { Unstable performance } \\
\text { Errors in warming up } \\
\text { Injuries } \\
\text { Coach approach in training } \\
\text { Static performance }\end{array}$ & \multirow[t]{4}{*}{$\begin{array}{l}\text { Psychological } \\
\text { Strength } \\
\text { (Acceptance } \\
\text { and } \\
\text { Commitment) }\end{array}$} & \multirow[t]{4}{*}{$\begin{array}{l}\text { Do not think about the } \\
\text { anxiety } \\
\text { Just face all the } \\
\text { possibilities }\end{array}$} \\
\hline $\begin{array}{l}\text { Change } \\
\text { Issues }\end{array}$ & $\begin{array}{l}\text { Body composition } \\
\text { Eating habits } \\
\text { Training schedule } \\
\text { Training place } \\
\text { Training equipment } \\
\text { Coach changes } \\
\text { Organizational management } \\
\text { Sports facilities } \\
\text { Accommodation facilities } \\
\text { Patterns of family } \\
\text { relationships } \\
\text { Patterns of socialization } \\
\text { Lifestyle } \\
\text { Financial } \\
\text { Reward issues }\end{array}$ & & \\
\hline $\begin{array}{l}\text { Behavioral } \\
\text { Issues }\end{array}$ & $\begin{array}{l}\text { Not getting enough sleep } \\
\text { Improper eating habits } \\
\text { Always think about training } \\
\text { programs } \\
\text { Discipline problem } \\
\text { Taking prohibited substances } \\
\text { Smoking } \\
\text { Consuming alcoholic } \\
\text { beverages }\end{array}$ & & \\
\hline $\begin{array}{l}\text { Psychological } \\
\text { Issues }\end{array}$ & $\begin{array}{l}\text { Difficult to overcome nervous } \\
\text { Difficult to overcome anger } \\
\text { Can't wait for everything to } \\
\text { run out quickly } \\
\text { Difficult to overcome laziness } \\
\text { Difficult to overcome fatigue } \\
\text { Difficult to cope with mental } \\
\text { stress } \\
\text { Difficult to overcome } \\
\text { sleepiness } \\
\text { Difficult to cope with pain } \\
\text { due to injury }\end{array}$ & & \\
\hline
\end{tabular}




\begin{tabular}{|l|l|l|l|}
\hline Interpersonal & Relationship issues with: & & \\
Issues & coach & & \\
& teammates & & \\
& management & & \\
& family members & & \\
\hline
\end{tabular}

Based on the themes and indicators, this clearly shows that athletes must be able to cope with stress experiences quickly and efficiently (Carver \& Schieier, 1998). They also should remain with PD status and achieve a balanced level of performance (Luthar, Cicchetti \& Becker, 2000) after stress experienced. Resilience will be achieved if athletes are sensitive to the risk factors encountered as a result of the interaction between personal, cultural, social and political surroundings (Giligan, 2004). In addition, researchers also found that the main protective factor used by athletes is acceptance and commitment. This is in line with the view of Fletcher and Sarkar (2013) that personal assets are needed in protecting individuals from the negative effects of stressors. Therefore, based on this study, a model of resilience in sport for PD athlete is provided as shown in Figure 2.

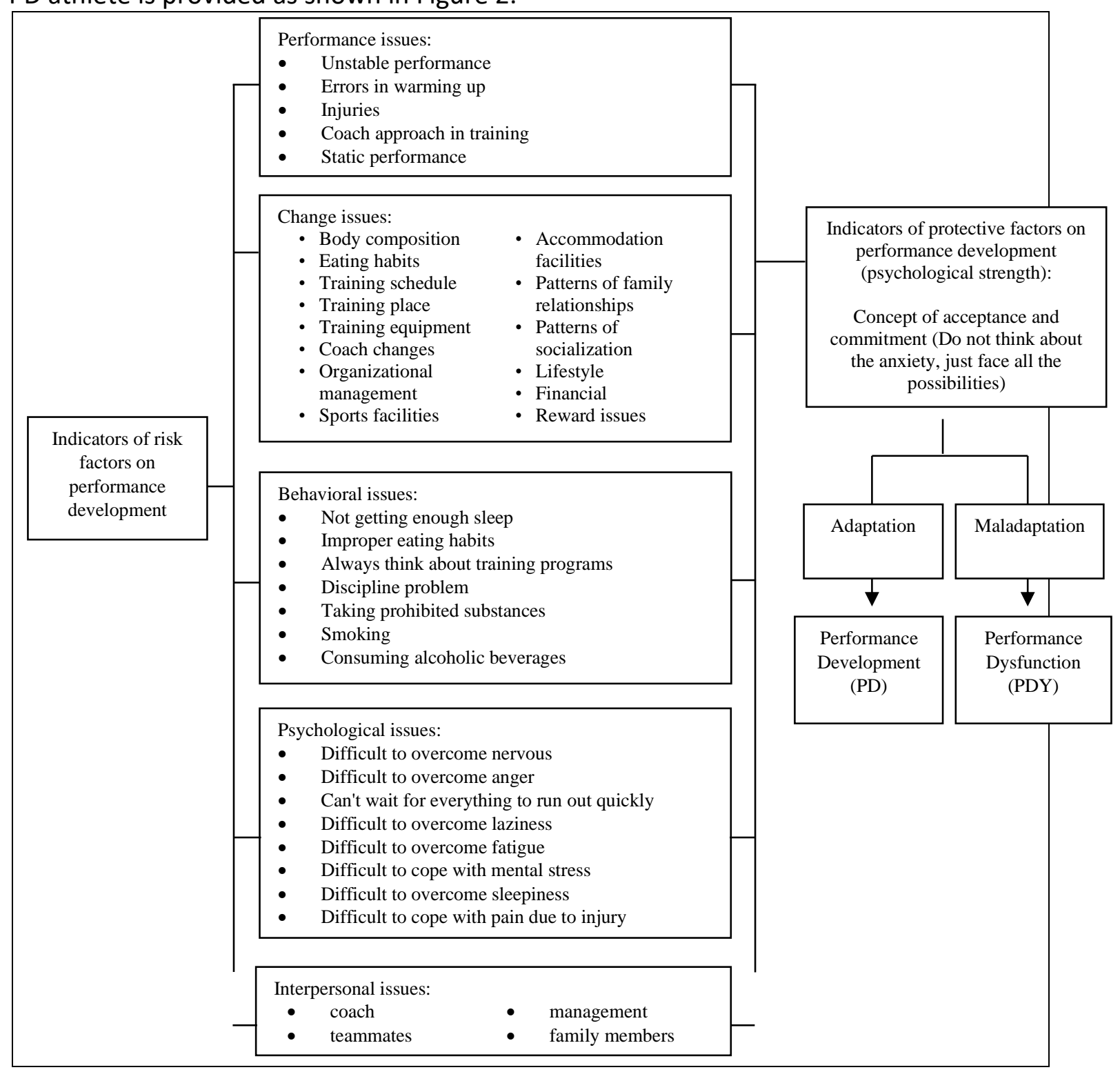

Figure 2

Mode of Resilience in Sportl for Performance Development (PD) Athletes 
It is clearly stated in Figure 2 that the tendency of PD athletes to address risk factors can affect the performance function of athletes. Based on MCS-SP model, if PD athletes are prone to psychological risk factors beyond performance issues, then the performance status of athlete will change to the level of Performance Dysfunction (PDy). According to Gardner and Moore (2006) PDy athletes usually have a good level of psychological development, however, there are some psychological barriers such as developmental problems, change, interpersonal, intrapersonal and the formation of schemes and perceptions, which negatively affect athlete performance. This condition can hinder the development of sports performance, while psychological function and physical behavior are declining. The concept of acceptance and commitment seems to be the most effective protective factors as athletes said that they do not think about the anxiety and just face all the possibilities. As Gardner and Moore (2007) stated, believing that avoiding negative thoughts and emotions will only lead to greater behavioral problems (Gardner \& Moore, 2007), Khalid et al (2019) also found that athletes can improve the development of aerobic performance with the concept of acceptance and commitment when they trained to adapt with the technique of Mindfulness Acceptance Commitment - Physical (MAC-P). Therefore, to ensure that PD status can be maintained, athletes must use protective factors to address risk factors, thus resilience will be remained.

\section{Acknowledgment}

This paper is based on the research project entitled Construction of Athlete Resilience Index Instrument (ARI) based on Multi Level Classification System Model for Sport Psychology. The authors would like to extend their gratitude to Universiti Pendidikan Sultan Idris for the University Research Grants (code: 2019-0213-106-01) that helped fund the research.

\section{References}

Burrows, D., \& Kendall, S. (1997). Focus groups: What are they and how can they be used in nursing and health care research? Social Sciences in Health, 3, 244-253.

Campbell-Sills, L., Cohan, S. L., \& Stein, M. B. (2006). Relationship of resilience to personality, coping, and psychiatric symptoms in young adults. Behavior Research and Therapy, 44, 585-599.

Carver, C. S., \& Scheier, M. F. (1998). On the self-regulation of behavior. New York: Cambridge University Press

Fern, E. F. (1982). The use of focus groups for idea generation: The effects of group size, acquaintanceship and moderation on response quantity and quality. Journal of Marketing Research, 19, 1-13.

Fletcher, D., \& Hanton, S. (2003). Sources of organizational stress in elite sports performers. The Sport Psychologist, 17, 175-195

Fletcher, D., \& Sarkar, M. (2012). A grounded theory of psychological resilience in Olympic champions. Psychology of Sport and Exercise, 13, 669-678.

Fletcher, D., \& Sarkar, M. (2013). Psychological resilience: A review and critique of definitions, concepts and theory. European Psychologist, 18, 12-23.

Galli, N., \& Vealey, R. S. (2008). "Bouncing back" from adversity: Athletes' experiences of resilience. The Sport Psychologist, 22, 316-335.

Gardner, F. L., Wolanin, A. T., Moore, Z. E. (2005). Mindfulness-Acceptance-Commitment (MAC) based performance enhancement for Division I athletes: A preliminary investigation. Manuscript submitted for publication

Gardner, F. L., \& Moore, Z. E. (2006). Clinical sport psychology. Champaign, IL: Human Kinetics. 
Gilligan, R. (2004). Promoting resilience in child and family social work: Issues for social work practice, education and policy. Social Work Education, 23(1), 93-104.

Glaser, B. G., \& Strauss, A. L. (1967). The discovery of grounded theory: strategies for qualitative research. New York: Aldine de Gruyter

Gucciardi, D., \& Gordon, S. (2009). Development and preliminary validation of the Cricket Mental Toughness Inventory (CMTI). Journal of Sports Science, 27, 1293-1310.

Hayward, C., Simpson, L., \& Wood, L. (2004). Still left out in the cold: Problematizing participatory research and development. Sociologia Ruralize, 44, 95-108

Hill, Y., Den Hartigh, R. J. R., Meijer, R. R., De Jonge, P., \& Van Yperen, N. W. (2018). Resilience in sports from a dynamical perspective. Sport, Exercise, and Performance Psychology, 7(4), 333-341

Hosseinia, S., A., S. A., \& Besharata, M. A. (2010). Relation of resilience whit sport achievement and mental health in a sample of athletes. Procedia Social and Behavioral Sciences, 5, 633-638

Howe, A., Smajdor, A., \& Stokl, A. (2012). Towards an understanding of resilience and its relevance to medical training. Medical Education, 46, 349-356.

Krueger, R. A. (1994). Focus groups: A practical guide for applied research. Thousand Oaks, CA: Sage Publications Inc.

Krueger, R. A., \& Casey, M. A. (2000). Focus groups: A practical guide for applied research, 4th ed. Thousand Oaks, CA: Sage Publications Inc.

Leipold, B., \& Greve, W. (2009). Resilience: A conceptual bridge between coping and development. European Psychologist, 14, 40-50.

Luthar, S. S., Cicchetti, D., \& Becker, B. (2000). The construct of resilience: A critical evaluation and guidelines for future work. Child Development, 71(3), 543-562.

Machida, M., Irwin, B., \& Feltz, D. (2013). Resilience in competitive athletes with spinal cord injury: The role of sport participation. Qualitative Health Research, 23(1), 1054-1065.

MacNamara, A., Button, A., \& Collins, D. (2010a). The role of psychological characteristics in facilitating the pathway to elite performance. Part 1: Identifying mental skills and behaviors. The Sport Psychologist, 24, 52-73

McCubbin, H. I., McCubbin, M. A., Thompson, A. I., Han, S., \& Chad, T. (1997). Families under stress: What makes them resilient. AAFCS Commemorative Lecture.

McKay, J., Niven, A. G., Lavallee, D., \& White, A. (2008). Sources of strain among UK elite athletes. The Sport Psychologist, 22, 143-163.

Mellalieu, S., Shearer, D., \& Shearer, C. (2013). A Preliminary Survey of Interpersonal Conflict at Major Games and Championships. Sport Psychologist, 27. 120-129.

Mendes de Almeida, P. F. (1980). A review of group discussion methodology. European Research, 8, 114-120.

Mills, A., Butt, J., Maynard, I., \& Harwood, C. (2014). Toward an Understanding of Optimal Development Environments Within Elite English Soccer Academies. Sport Psychologist, 28. 137-

Khalid, M. N. H., Rasyid, M. N., \& Abdul Razak, N. (2019). Pembinaan modul latihan Mindfulness Acceptance Commitment-Physical (MAC-P) untuk daya tahan aerobik. Malaysian Journal of Movement, Health \& Exercise, 8(1), 67-81

Khalid, M. N. H. (2008). Profil Resilien Dalam Kalangan Pelajar Jurusan Sains Sukan. DAPENA (09-09-53-06), Universiti Pendidikan Sultan Idris 
Khalid, M. N. H., Isa, M. N., \& Fadhil, M. (2018). Mental skill assessment towards excellent achievement among MSSM 2018 Perak Ten-Pin bowling athletes. Jurnal Sains Sukan dan Pendidikan Jasmani 7 (2), 42-52

Morgan, D. L. (1988). Focus group as qualitative research. Newbury Park, CA: Sage Publications Inc.

Mummery, W. K., Schofield, G., \& Perry, C. (2004). Bouncing back: the role of coping style, social support and self-concept in resilience of sport performance. Athletic Insight, 6 , $1 \mathrm{e} 18$.

Papathomas, A., \& Lavallee, D. (2012). Eating disorders in sport: A call for methodological diversity. Revista Psicologia Del Deporte, 21.

Parker, A., \& Tritter, J. (2006). Focus group method and methodology: Current practice and recent debate. International Journal of Research \& Method in Education, 29, 23-37.

Podlog, L., \& Eklund, R. C. (2006). A longitudinal investigation of competitive athletes' return to sport following serious injury. Journal of Applied Sport Psychology, 18(1), 44-68

Rutter, M. (2012). Resilience: Causal pathways and social ecology. In M. Ungar (Ed.), The social ecology of resilience: A handbook of theory and practice (pp. 33-42). New York, NY: Springer

Sarkar, M., \& Fletcher, D. (2014). Psychological resilience in sport performers: A review of stressors and protective factors. Journal of Sports Sciences, 32, 1419-1434

Stewart, D. W., Shamdasani, P. N., \& Rook, D. W. (2007). Focus groups: Theory and practice. Thousand Oaks, CA: Sage Publications Inc.

Ungar, M. (2008). Resilience across cultures. British Journal of Social Work, 38, 218-235.

Westphal, M., \& Bonanno, G. A. (2007). Posttraumatic growth and resilience to trauma: Different sides of the same coin or different coins? Applied Psychology: An International Review, 56, 417-427

Windle, G. (2011). What is resilience? A review and concept analysis. Reviews in Clinical Gerontology, 21, 152-169 